\title{
Korzul Clinical Practice Attitude Scale Validity and Reliability Study
}

\author{
Yalçın Kanbay $^{1}$ (D) , Pınar Tektaş² (D) , Elif Işık ${ }^{3}$ iD , Özgür Aslan ${ }^{4}$ (D) \\ Aysun Akçam ${ }^{5}$ iD , Sevil Çınar ${ }^{3}$ (D)
}

${ }^{1}$ Department of Psychiatric Nursing, Faculty of Health Sciences, Artvin Coruh University, Artvin, Turkey

${ }^{2}$ European University of Lefke, Higher School of Health, Nursing Department, Cyprus

${ }^{3}$ Faculty of Health Sciences, Artvin Çoruh University, Artvin, Turkey

${ }^{4}$ Vocational School of Health Services, Kafkas University, Kars, Turkey

${ }^{5}$ Necmettin Erbakan University, Kırşehir, Turkey

\section{Yalçın KANBAY \\ Pınar TEKTAŞ \\ Elif IŞIK \\ Özgür ASLAN \\ Aysun AKÇAM \\ Sevil ÇINAR}

This study has been presented orally at Palandöken International Nursing Education Congress on Paediatric Nursing, December 18-19, 2020, Turkey.

\section{Correspondence: Sevil Çınar} Faculty of Health Sciences, Artvin Çoruh University, Artvin, Turkey

Phone: +9004662151064

E-mail: cinarsevil87@gmail.com

$\begin{array}{ll}\text { Received } & : 25 \text { July } 2021 \\ \text { Accepted } & : 180 \text { ctober } 2021\end{array}$

\section{ABSTRACT}

Purpose: In this study, it was aimed to develop the "Korzul clinical practice attitude scale" in order to determine the attitudes of students in health branch, who perform clinical practices such as nursing, midwifery and elderly care program, etc., towards clinical practice.

Methods and Materials: An experiment form consisting of 44 expressions validated in terms of language and psychometry was applied to a sample of 1203 participants, of which 68\% were female and whose age range was 18-34 years. In order to test the reliability of the scale, the Cronbach's alpha reliability coefficient and test-retest consistency were calculated.

Results: The developed "Korzul clinical practice attitude scale" consists of 4 sub-dimensions and 25 items, and it can explain 52.9 of the total variance for clinical practice attitudes. The total score of the scale ranges from 25 to 125 , and the increase in score means a positive attitude towards clinical practice. The general Cronbach's alpha reliability coefficient of the scale was calculated as .90 , which indicates high reliability.

Conclusions: According to the results, it is observed that the "Korzul clinical practice attitude scale,"of which validity and reliability study was performed for the purpose of measuring attitudes towards clinical practice, can perform measurements in a valid and reliable way.

Keywords: Clinical practice, validity, reliability

\section{Korzul Klinik Uygulama Tutum Ölçeği Geçerlik ve Güvenilirlik Çalışması}

ÖZET

Amaç: Bu çalışmada, hemşirelik, ebelik ve yaşıı bakımı gibi klinik uygulamaları gerçekleştiren sağlık alanındaki öğrencilerin klinik uygulamaya yönelik tutumlarının belirlenmesi amacılla "Korzul klinik uygulama tutum ölçeği" nin geliştirilmesi amaçlanmıştır.

Yöntem: Dil ve psikometri açısından doğrulanmış 44 ifadelik deneme formu; \% 68'i kadın, yaş aralığı 18-34 olan 1203 katılımcıdan oluşan bir örnekleme uygulanmıştı. Ölçeğin güvenirliğini test etmek için Cronbach alfa güvenirlik katsayısı ve test- tekrar test tutarlıı̆̆ı hesaplanmıştır.

Bulgular: Geliştirilen "Korzul klinik uygulama tutum ölçeği" 4 alt boyut ve 25 maddeden oluşmakta olup, klinik uygulama tutumları için toplam varyansın 52.9'unu açıklayabilmektedir. Ölçeğin toplam puanı 25 ile 125 arasında değişmekte olup, puanın artması klinik uygulamaya yönelik olumlu bir tutum anlamına gelmektedir. Ölçeğin genel Cronbach alfa güvenirlik katsayısı .90 olarak hesaplanmıştır ve bu yüksek güvenilirliği gösterir.

Sonuç: Elde edilen sonuçlara göre, klinik uygulamaya yönelik tutumları ölçmek amacıyla geçerlik ve güvenirlik çalışması yapılan "Korzul klinik uygulama tutum ölçeğinin" ölçümleri geçerli ve güvenilir bir şekilde yapabildiği görülmektedir.

Anahtar kelimeler: Klinik uygulama, Geçerlilik, Güvenilirlik 


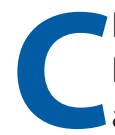
linical practices are practices that allow students to learn by practicing/experiencing in a real setting and contribute positively to communicating with healthy/sick individuals using professional knowledge and skills and contribute positively to problem-solving and decision-making skills $(1,2)$.

Clinical practice areas allow students to observe role models, practice alone by taking responsibility, act according to the patient's clinical situation both and individuality, make decisions, and work as a team member, giving students the opportunity to integrate the theoretical knowledge and practice taught in the school setting by experiencing and practicing in the real setting (3). The clinical settings selected in line with educational objectives contribute positively to the development of students, and it is stated that in cases when clinical education is not conducted in accordance with educational objectives and the rules of education are not taken into consideration, students learn by trial and error or imitation of examples they encounter $(4,5)$.

The importance of clinical practice in transforming theoretical knowledge into skills and improving the professional identity of students cannot be denied (6). However, the studies conducted show that clinical practices create stress for students. Furthermore, they show that they cannot be implemented exactly as desired due to the short period of time, the lack of skill-oriented practices, the clinical setting not meeting the educational objective, problems with observing role models and work-centered studies (7-9).

One of the reasons why clinical practice cannot be implemented as desired is that students have negative attitudes towards clinical practice. Attitude is a "tendency that is attributed to an individual and forms his/her thoughts, feelings, and behaviors with regard to a psychological object on a regular basis." An attitude affects an individual's thoughts, feelings, and behaviors by harmonizing them.

One of the bases for quality health service is education which encompasses the three domains of learning; knowledge, practice, and attitude (10). Students' attitudes towards clinical practice could be affected by student-staff interaction, clinical environment, clinical preceptors, and the availability of necessary equipment in a hospital setting $(11,12)$. If the attitude of health professionals is not favorable, the quality of health care could be compromised in a significant manner (11).
There is a significant incoherence between clinical practice and theory (13) and one of the causes of this discrepancy could be the attitude. A positive attitude towards clinical practice enhances effective clinical learning. Whereas, a negative attitude hampers the acquisition of essential clinical skills. Thus, identifying the gap in clinical practice is noteworthy for improving the quality of health professional's educations(12)

Attitudes toward clinical practice depend on close collaboration between clinical staff and school educators who are especially responsible for the students' clinical education as a preceptor $(14,15)$. Therefore, developing highquality clinical environments between the school and hospital are cornerstones in optimizing clinical practice $(16,17)$. Evaluating students' diverse attitudes, in particular, provide a helpful insight to facilitate the development of effective clinical teaching strategies in education (18). Consequently, the attitudes of each student toward clinical practice must be investigated before and after clinical practice, and the results must be also respected and reflected to maximize clinical learning outcomes(19).

When attitudes are fully developed, they become a complex tendency that prepares the individual for a behavior. Thus, the individual's feelings to various objects around him/her, his/her thoughts about the object and behaviors towards them show continuity and consistency (20). Accordingly, it is thought that the positive attitude towards clinical practice will affect the behaviors of students when they start the profession and all the aspects related to the profession positively.

Proper understanding of the attitudes of students toward clinical practice and reflection of these results in planning and evaluating clinical practice are the linchpin to achieve clinical learning objectives (19). In this context, it is thought that determining the attitudes of students towards clinical practice will contribute to the development of effective teaching strategies in vocational education. However, it is observed in the literature that students studying in clinical practice areas are not a measurement tool that measures clinical practice attitudes. Therefore, the aim of this study was to develop a measurement tool that can be used to measure the clinical practice attitudes of students towards the professions involved in clinical practice. The scale, which is planned to be developed, has a unique value since it is the first measurement tool that allows measuring the clinical practice attitudes of 
students who receive healthcare education and are involved in clinical practice areas.

\section{MATERIAL AND METHODS}

Design

The development of the clinical practice attitude scale consisted of several stages. These stages include the examination of the theoretical structure, ethical practices, item writing, the creation of the draft form, pilot study, expert opinion, the creation of the trial form, the application of the trial form to the sample, findings (validity and reliability), and the finalization of the scale.

Examination of the theoretical structure: At this stage, the conceptual framework of the subject was determined by reviewing the literature on clinical practice, and the previous studies on the subject were reviewed.

Ethical practices: Ethical permissions required for the study were obtained from University Scientific Research and Publication Ethics Committee (session dated 18.05.2017 and numbered 2017/3 and decision no: 9). The permission of the institutions where the data collection stage was carried out was obtained. These institutions are Bingöl University (letter dated 04.10.2017 and numbered 8836), Kafkas University (letter dated 23.10.2017 and numbered 9535), Maltepe University (letter dated 06.10.2017 and numbered 8929), Recep Tayyip Erdoğan University (letter dated 06.10.2017 and numbered 8910).

Creation of the question pool: This stage consisted of a literature review, composition writing, and focus group interview. At the stage of the literature review, studies related to clinical practice in online and printed sources were examined, and statements that might be an attitude were included in the question pool. At the composition-writing stage, students were asked to write down their feelings, thoughts, and behaviors related to clinical practice by distributing notepads to them. Afterward, the notepads in which the students had written were collected and content analyses, and the statements containing the attitudes towards clinical practice were added to the question pool. At the focus group interview stage, a group of 8 students was interviewed as recommended in the literature (21). The statements obtained during the interview process were added to the question pool. After these procedures, the question pool consisted of a total of 55 statements.
Creation of the draft form: At this stage, it was decided with the help of the expert's opinion that a 5-point Likert type of the questionnaire would be useful and convenient for this study. Likert-type scales are commonly used in instruments that measure thoughts, beliefs, and attitudes by combining multiple Likert-type questions $(22,23)$. Likert-type scales are one of the methods for placing individuals on the psychological dimension according to the predetermined stimuli, criteria, or set of criteria (24). After deciding on the type of the questionnaire, the expert's opinion was again taken into consideration, and the questionnaire was transformed into a 5-point Likert-type draft form with the responses of "Totally Disagree," "Disagree," "Moderately Agree," "Agree," and "Totally Agree."

Pilot study: After the draft form is created, a pilot study is required to determine whether these statements are understood correctly by the sample. It is stated in the literature that 30-50 people may be sufficient for a pilot study (25). For this reason, the 55-item draft form was applied to a sample of 52 people with similar characteristics to the study sample. As a result of the application, it was determined that there were statements that were not understood or were misunderstood by students, and after the corrections were made, a draft form consisting of 49 statements was obtained.

Expert's opinion: For the content validity of the draft form, on which the necessary corrections were made after the pilot study, 6 experts (statistician, measurement and evaluation specialist, psychologist, nurse), who were academicians experienced in scale development studies and health sciences, were asked to submit their opinions. After the necessary corrections were made after the expert suggestions, the draft form was reduced to 46 statements. Afterward, this draft form consisting of 46 statements was evaluated by the experts in terms of Turkish language validity, and their opinions were received, and the questionnaire was corrected in terms of language and grammar. After the corrections, the draft form consisted of a total of 44 statements.

Creation of the trial form: The statements in the draft form were arranged as 1 = "Totally Disagree," 2 = "Disagree," 3 = "Moderately Agree," 4 = "Agree," 5 = "Totally Agree," and a trial form consisting of 44 statements was obtained. 
Application of the trial form to the sample: The obtained 44-item trial form was applied to a sample of 1244 people, $68 \%$ of whom were female, and the age range was $18-34$, and the mean age was $20.8 \pm 0.1$. The sample of the study consisted of 1203 people because of the exclusion of the participants who responded to the statements in the trial form incompletely or who were thought to have filled in the form randomly. The nonprobability sampling method was used in sample selection in accordance with the aim of the study. In nonprobability sampling, sampling units are selected consciously within the framework of certain criteria (26). Since the aim of this study was to determine the attitudes of students involved in clinical practice in the health branch towards clinical practice, only healthcare branches involved in clinical practice were included in the sample of the study. These branches include nursing $(n=589)$, midwifery $(n=133)$, elderly care ( $n=47)$, emergency medical technician $(n=268)$, medical imaging ( $n=46)$, and home health care $(n=120)$ branches. These healthcare branches were chosen because the clinical practice of the students was similar.

Two criteria were taken into consideration in determining the number of samples required for this study. One of them is the adequacy of the number of individuals to be included in the sample, and the other one is the KaiserMeyer-Olkin (KMO) test to determine the adequacy of the data obtained from the sample. Although there are various suggestions in the literature for the sample size to be taken into consideration in scale development studies, there is little consensus among authors regarding how large the sample should be (27). One of them is the rule of 10 . According to this rule, there should be at least 10 participants per variable (26). Ho (2006) suggested that the number of samples should not fall below 100 to perform factor analysis (p.207), while Comrey and Lee stated that 100 is poor, 200 is moderate, 300 is good, 500 is very good, and 1000 is excellent (28). In the evaluation of $\mathrm{KMO}$, the $\mathrm{KMO}$ value is considered to be excellent as it approaches 1 and unacceptable if it is below 0.50. According to this evaluation, $0.50 \mathrm{~s}$ are considered to be poor, $0.60-0.70 \mathrm{~s}$ as moderate, 0.80 s as very good, and 0.90 s as excellent (29). The fact that the number of samples is over 1000 and the $\mathrm{KMO}$ value is 0.952 in this study shows that the number of samples is excellent and the data obtained from the sample are adequate.

Validity and Reliability: Validity is that the measurement tool used corresponds to the feature to be measured, the data fully reflect the quality of the feature to be measured, and the data are useful for the purpose (26).
Reliability is that test or scale results accurately reveal the fact related to the conceptual structure, and the measurement tool gives similar results when applied in different locations, at different times, and in different masses selected from the same main mass (26).

In order to determine the construct validity of the scale developed to determine attitudes towards clinical practice, "Principal Component Analysis," which is one of the "Exploratory Factor Analysis" techniques, was used. The exploratory factor analysis is used to collect the items in the measurement tool under certain sub-factors (30). In factor analysis, when factors are determined for the first time, since most variables are collected in the most important factor with the highest load, they are not apparent and, therefore, difficult to interpret (31). For this reason, the "convergence" procedure is performed. At the end of convergence, factors find items that are highly correlated with them, and as a result, factors become easier to interpret (31). If there is no theoretical structure that requires factors to be correlated with each other in the convergence procedure, "vertical convergence techniques" are used, and if there is a structure that requires factors to be correlated with each other, "oblique convergence techniques" are used $(30,31)$.

In this study, since it is thought that there may be a correlation between the factors and a structure consisting of theoretically related factors is desired to be created, the "direct oblimin technique," which is one of the oblique techniques, was used as the factor convergence technique, and the maximum iterations for convergence were used as 12. Furthermore, confirmatory factor analysis (CFA) was performed to test the resulting structure. For the internal validity of the scale, $27 \%$ subgroup-supergroup comparisons were made. Cronbach's a reliability coefficient and test-retest consistency were used for the reliability of the scale.

\section{RESULTS}

In this section, preliminary statistics and findings related to the validity and reliability of the scale are given.

\section{Preliminary statistics}

At this stage, first, the suitability of the data for factor analysis was investigated. In order to determine the suitability of the data for factor analysis, it is recommended to ensure item reliability, calculate the Kaiser-Meyer-Olkin (KMO) coefficient, and perform Bartlett's sphericity test before factor analysis $(24,32)$. 
Item reliability, i.e. mean item-total score correlation coefficients

It shows the correlation between the total scores of the five-or seven-degree scale in attitude scales (indices) and the scale/test, which may also consist of double-digit values, in knowledge and achievement tests, and the scores of each item (26). If the item-total score correlation coefficient is below .30, it should be considered that there is a problem in the item, and it should be changed or removed from the scale.

The item-total item correlation of the clinical practice attitude scale is presented in Table 1. In the analysis, it was determined that the correlation coefficients of 6 items (items M8, M20, M28, M42, M43, and M44) were below .30 and were therefore excluded from the scale. The correlation coefficients of the remaining 38 items ranged from .36 to .64 .

\section{Kaiser-Meyer-Olkin (KMO) coefficient and Bartlett's sphericity test}

The KMO coefficient provides information about whether the data matrix is suitable for factor analysis and whether the data structure is suitable for factor extraction. The KMO coefficient is expected to be above .60. Bartlett's test examines the relationship between variables on the basis of partial correlations. The fact that the calculated chi-square statistic is significant can be regarded as a proof of the normality of the scores (32). The KMO value was found to be .95 , and Bartlett's test result was found to be $21444.388(p<.0001)$ for 38 items evaluated in order to develop a clinical practice attitude scale. These values indicate that the trial form is suitable for factor analysis.
Validity

While the validity of the scale was examined, construct validity and internal validity were examined. Factor analysis was used to determine construct validity, and a subgroup-supergroup comparison was performed to determine internal validity.

Construct Validity: Construct validity was analyzed by factor analysis. Factor analysis is a multivariate statistic, which aims to find and explore a few unrelated new variables and conceptually significant new variables (factors, dimensions) by bringing together the related $p$ variables (32). Various criteria are proposed in the literature for item selection in factor analysis. The first one is related to the item factor load value. Although the factor load value of the items of 0.45 and above is a suitable criterion for selection, this value can decrease to 0.30 . In this study, items with a factor load value of 0.45 and above were selected in item selection. The second criterion is that items have high load values in one factor and low load values in other factors. The difference between the two high load values is recommended to be at least .10 $(30,32)$. In this study, this criterion was taken into consideration, and items with at least .10 value between two load values were evaluated as overlapping items and were excluded from the process. As a result of the factor analysis, 9 items with a factor load value below .45 and 4 overlapping items were excluded from the study, and the study was continued with the 25 item trial form.

\begin{tabular}{|c|c|c|c|c|c|c|c|}
\hline Item No & Item Corelation & Item No & Item Corelation & Item No & Item Corelation & Item No & Item Corelation \\
\hline M1 & .607 & M12 & .488 & M23 & .538 & M34 & .359 \\
\hline M2 & .381 & M13 & .478 & M24 & .505 & M35 & .589 \\
\hline M3 & .513 & M14 & .482 & M25 & .505 & M36 & .544 \\
\hline M4 & .491 & M15 & .576 & M26 & .210 & M37 & .550 \\
\hline M5 & .551 & M16 & .469 & M27 & .586 & M38 & .473 \\
\hline M6 & .644 & M17 & .385 & *M28 & .238 & M39 & .535 \\
\hline M7 & .540 & M18 & .583 & M29 & .513 & M40 & .576 \\
\hline *M8 & .264 & M19 & .508 & M30 & .571 & M41 & .532 \\
\hline M9 & .403 & *M20 & .276 & M31 & .530 & ${ }^{*} \mathrm{M} 42$ & .296 \\
\hline M10 & .431 & M21 & .419 & M32 & .577 & ${ }^{*}$ M43 & .284 \\
\hline M11 & .545 & M22 & .487 & M33 & .442 & ${ }^{*} \mathrm{M} 44$ & .224 \\
\hline
\end{tabular}


Exploratory factor analysis was performed to determine the factorization of the scale. The exploratory factor analysis is a process used to determine the number of headings for items (variables) in a measurement tool prepared as a draft and applied to find factors based on the relationships between the variables, and is a method frequently used to examine the construct validity of the scale $(30,32)$. When determining the number of factors to be included in a scale, each sub-dimension must have an eigenvalue of at least 1 and above and explain at least $5 \%$ of the variance in the factor analysis. Moreover, it is accepted as a principle that the variance explained by the scale is larger than the variance that the scale cannot explain (30). In addition, examining the line graph of factor analysis is one of the methods that help researchers to decide how many factors the scale will consist of. In this study, maximum attention was paid to these criteria. While determining factors, it was ensured that each factor had an eigenvalue greater than 1 and explained at least $5 \%$ of the variance, and the total variance was over $50 \%$, and item selection was made in this direction. As a result of the factor analysis and line graph analysis performed according to these criteria, it was decided that the scale could consist of 4 factors, each explaining at least $5 \%$ of the variance and having an eigenvalue greater than 1 . Table 2 shows the eigenvalue and variance percentages of the obtained clinical practice attitude scale according to the factor groups.

\begin{tabular}{|c|c|c|c|}
\hline Factors & Eigenvalue & $\begin{array}{l}\text { Variance } \\
\text { Percentage } \\
\text { (\%) }\end{array}$ & $\begin{array}{l}\text { Total Variance } \\
\text { Percentage } \\
\text { (\%) }\end{array}$ \\
\hline Factor 1 & 7.61 & 31.7 & 31.7 \\
\hline Factor 2 & 2.41 & 10.0 & 41.8 \\
\hline Factor 3 & 1.46 & 6.1 & 47.8 \\
\hline Factor 4 & 1.23 & 5.1 & 52.9 \\
\hline
\end{tabular}

In this 4-factor scale obtained, the first factor explained $31.7 \%$ of the total variance, the second factor explained $10.0 \%$ of the total variance, the third factor explained $6.1 \%$ of the total variance, and the fourth factor explained $5.1 \%$ of the total variance. Together, four factors explained $52.9 \%$ of the total variance.
The first factor consists of 6 items, and the factor load values of the items vary between .509 and .828 . The second factor consists of 9 items, and the factor load values of the items vary between .544 and .710 . The third factor consists of 4 items, and the factor load values of the items vary between .494 and .774 . The fourth factor consists of 6 items, and the factor load values of the items vary between .479 and .724 (Table 3).

Confirmatory factor analysis (CFA) was applied to the data in order to test the validity of the four-factor structure obtained from the principal component analysis. Compliance of the data obtained from the study with the measurement model was tested with $\mathrm{X}^{2} / \mathrm{sd}$, RMSEA, $\mathrm{GFI}, \mathrm{CFI}$, and NFI indices, and good fit criteria for each index obtained are given in Table 1 . Since the $\mathrm{X}^{2} / \mathrm{sd}$ value (4.38) of the four-factor model is less than 5 , the model meets the compliance criteria in this respect. In addition, it seems to be compatible with the data in terms of the $\mathrm{GFI}=0.92, \mathrm{CFI}=0.93, \mathrm{NFI}=0.91$, and $\mathrm{RMSEA}=0.05$ indicators $(33,34)$.

Internal validity: Whether the items, which were decided to leave in the scale, had internal validity, was tested by the "independent samples t-test."The test scores obtained from the scale were ranked from small to large, and $27 \%$ of the sample consisted of 324 people. Afterward, according to the scale score, 324 people with the lowest score were re-coded as the "subgroup," and 324 people with the highest score were re-coded as the "supergroup." The remaining persons were not included in the process. After this process, whether the difference between the subgroup and the supergroup was significant was examined by the "independent samples t-test." The findings obtained are presented in Table 4.

When the findings of internal validity were examined, it was observed that the difference between the mean scores of the clinical practice attitude scale of the subgroup and the super group was significant $(p<0.001)$. According to this finding, it can be said that the clinical practice attitude scale distinguishes individuals with positive attitudes towards clinical practice from individuals with negative attitudes, in other words, it has internal validity. 


\section{Table 3. Factor Items and Item Factor Load Values}

\begin{tabular}{|c|c|c|c|c|c|}
\hline Item No & Statement & Factor 1 & Factor 2 & Factor 3 & Factor 4 \\
\hline M2 & I feel sufficient in clinical practice. & .828 & & & \\
\hline M3 & In practice, I see myself as a member of the clinic. & .766 & & & \\
\hline M4 & I am making efforts to solve problems related to the practice. & .699 & & & \\
\hline M5 & I'm trying to take advantage of clinical learning opportunities. & .663 & & & \\
\hline M1 & I feel happy in the field of clinical practice. & .548 & & & \\
\hline${ }^{*} \mathrm{M} 6$ & I do not feel comfortable in the field of clinical practice. & .509 & & & \\
\hline${ }^{*} \mathrm{M} 18$ & I often disregard form integrity in clinical practice. & & .710 & & \\
\hline M27 & I prefer clinical practice rather than the classroom setting. & & .700 & & \\
\hline M19 & I like working with the clinical team. & & .686 & & \\
\hline M30 & Clinical practice makes it easier for me to learn professional skills. & & .669 & & \\
\hline${ }^{*} \mathrm{M} 11$ & Clinical practice turns me against this profession. & & .645 & & \\
\hline *M10 & I feel nervous on the day of clinical practice. & & .629 & & \\
\hline *M22 & I do not think that clinical practice prepares me for the profession. & & .606 & & \\
\hline${ }^{*} \mathrm{M} 21$ & I have difficulty in following the rules in clinical practice. & & .603 & & \\
\hline M40 & Being in the clinic increases my learning motivation. & & .544 & & \\
\hline M26 & I find clinical practice enjoyable. & & & .774 & \\
\hline *M17 & I look forward to the end of clinical practice. & & & .710 & \\
\hline M32 & I think clinical practice is an essential part of my education. & & & .518 & \\
\hline *M33 & In my opinion, clinical practice is a waste of time. & & & .494 & \\
\hline *M39 & I feel bad as long as I am in clinical practice. & & & & .724 \\
\hline M36 & I would like to have a longer clinical practice. & & & & .691 \\
\hline M29 & Clinical practice makes me love my profession. & & & & .585 \\
\hline *M9 & The clinical practice environment makes me very nervous. & & & & .531 \\
\hline${ }^{*} \mathrm{M} 16$ & I feel trapped in clinical practice. & & & & .531 \\
\hline *M25 & If I had a choice, I wouldn't want to participate in clinical practice. & & & & .479 \\
\hline
\end{tabular}

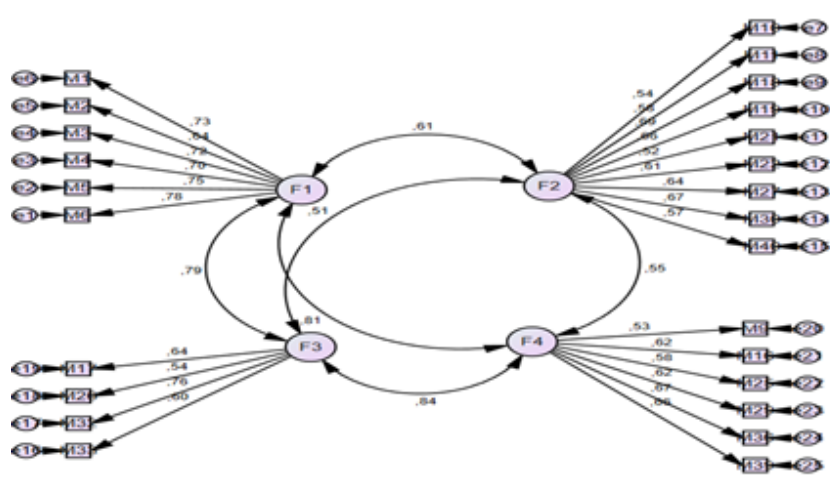

Figure 1. Confirmatory Factor Analysis (CFA) of a Four-Factor Structure
Table 4. Findings on the Internal Validity of the Clinical Practice Attitude Scale

\begin{tabular}{|l|c|c|c|c|c|}
\multicolumn{1}{|c|}{ Group } & $\mathrm{n}$ & Mean & $\begin{array}{c}\text { Standard } \\
\text { Error }\end{array}$ & $\mathrm{t}$ & $\mathrm{p}$ \\
\hline Subgroup & 324 & 69.65 & .397 & \multirow{2}{*}{-72.840} & \multirow{2}{*}{.000} \\
\cline { 1 - 4 } Supergroup & 324 & 107.33 & .332 & & \\
\hline${ }^{*} \mathrm{P}<0.001$ & & & \\
\hline
\end{tabular}

Table 5. Findings on the Internal Validity of the Korzul Clinical Practice Attitude Scale

\begin{tabular}{|l|l|l|}
\hline \multicolumn{1}{|c|}{ Factor } & \multicolumn{1}{c|}{ Factor name } & Cronbach's a value \\
\hline Factor I & Adoption & .846 \\
\hline Factor II & Harmony & .840 \\
\hline Factor III & Caring & .715 \\
\hline Factor IV & Clinical preference & .770 \\
\hline Total & & .895 \\
\hline
\end{tabular}




\section{Reliability}

In Likert-type scales, firstly, internal consistency should be ensured. Internal consistency is related to the extent to which the items of the scale are compatible with each other. The best way to do this is to calculate Cronbach's a reliability coefficient. In addition, reliability can be tested by means of test-retest if necessary $(27,35)$. In this study, Cronbach's a reliability coefficient and test-retest consistency were calculated to test the reliability of the scale.

Cronbach's Alpha: Reliability coefficients can be calculated by using different methods in the development of measurement tools developed to measure cognitive and affective characteristics. One of these methods is Cronbach's alpha (Cronbach's a) reliability. It is desirable that the reliability coefficient, which can be considered sufficient in a Likert-type scale, is above .70, but it should be as close to 1 as possible $(23,35)$. For research scales, the Cronbach's a value below .60 is unacceptable; the value between .60 and .65 is not desirable; the value between .65 and .70 is acceptable at a minimum; the value between .70 and .80 is remarkable; the value between .80 and .90 is very good, and it is suggested that the researcher should consider shortening the scale if it is far above .90 (23).

In this study, the Cronbach's a value was determined to be .90 for the overall scale. This value determined indicates that the reliability of the items in the scale is high and they aim to measure the same attitude. In other words, it can be said that this scale reliably distinguishes attitudes towards clinical practice. Cronbach's a values of the scale and its sub-dimensions are presented in Table 5.

\section{Test-Retest Consistency}

In addition to the Cronbach's a reliability coefficient, the test-retest consistency of the scale was calculated for the reliability of the scale. This method was preferred because it was not expected that there would be a significant change in students' attitudes towards clinical practice. Test-retest reliability is a measure of the ability of a measurement tool to deliver consistent results from application to application (35). In this study, the 25-item form, which was validated with 54 individuals from the study population, was applied at 4-week intervals for test-retest reliability. As a result of this application, there was no statistically significant difference between the two measurements ( $p>0.05$ ). According to this finding, it was determined that the scale obtained was reliable and it measured attitudes towards clinical practice reliably.
Finalization of the scale

In this study, the "Korzul Clinical Practice Attitude Scale" was aimed to be developed in order to measure the attitudes of students receiving education in healthcare branches towards clinical practice. The analyses show that the Korzul Clinical Practice Attitude Scale is acceptable in terms of scope, content, and structure. The 25 -item scale obtained was renumbered from 1 to 25 , with item numbers ranging from small to large, and the form was finalized (Appendix 1).

\section{Scale instruction}

According to the findings obtained, it is observed that this scale, of which validity and reliability studies have been carried out, can perform measurements in a valid and reliable way in order to measure attitudes towards clinical practice.

The developed "clinical practice attitude scale" consists of 4 sub-dimensions and 25 items and can explain $52.9 \%$ of the total variance for attitudes towards clinical practice. The 1st factor consists of items 1, 5, 12, 13, 19, and 23, and its Cronbach's a reliability coefficient is .85 . The 2 nd factor consists of items $4,6,7,10,11,14,15,16$, and 20, and its Cronbach's a reliability coefficient is .84. The 3rd factor consists of items 2, 18,21, and 24, and its Cronbach's a reliability coefficient is .72. The 4th factor consists of items 3 , $8,9,17,22$, and 25 , and its Cronbach's a reliability coefficient is .77. The overall Cronbach's a reliability coefficient of the scale was calculated to be .90 , and this value indicates high reliability.

In the scoring of the scale, items $2,3,4,6,8,9,10,16,17$, 20,21 , and 23 are scored inversely. The total score that can be obtained from the overall scale varies between 25 and 125. A score above 75 indicates positive attitudes towards clinical practice, and a score below 75 indicates negative attitudes. In the studies, the sub-dimensions of the scale can be evaluated separately, and researchers who require a high level of reliability and validity in their studies are recommended to carry out processes based on the total score of the scale.

The validity and reliability studies of the scale were performed with at least associate degree students in healthcare branches nursing, midwifery, elderly care program, emergency medical technician, medical imaging, and home health care. It is recommended that researchers, who will carry out studies in other branches other than 
these branches, should test the reliability of the scale in their studies.

\section{CONCLUSION AND RECOMMENDATIONS}

Attitudes consist of individuals' feelings, thoughts, and behaviors towards an object of attitude. The individual's feelings, thoughts, and behaviors towards the object of attitude shape the perception of that object of attitude and relationship with the object of attitude. Therefore, the determination of attitudes towards the object of attitude will allow us to know the reactions of the person to the object of attitude in advance and to plan initiatives for this. The clinical setting, which is an important object of attitude for students involved in clinical practice, creates various positive or negative attitudes in the student. The clinical performance of the student, his/her clinical and academic achievement, quality of patient care, job satisfaction, student-team relationships, professional satisfaction, and many other factors that cannot be counted are shaped according to the developing clinical attitude of the student. For this reason, it is important to determine the attitudes of students towards clinical practice and to make initiatives for this. This developed scale is intended to provide researchers with opportunities in this regard.

\section{Limitations and further research}

There are some limitations in this study. First, this study focused on students in healthcare branches nursing, midwifery, elderly care program, emergency medical technician, medical imaging, and home health care. We have not examined other healthcare branches. Second, this study was conducted only in Turkey. Therefore, we do not know how differences between countries may affect the validity of the scale. In future research, studies should be conducted in other countries to develop a cross-culturally.

\section{Ethical approval}

Ethics committee approval was received for this study from the Non-interventional Clinical Trials Ethic Committee of University (number: 2017-E.9032).

\section{Author Contributions}

Concept/Design: YK, PT, El; Data acquisition: El, ÖA; Data analysis and interpretation: $Y K, A A$; Drafting manuscript: YK, PT, El; Critical revision of manuscript:YK, PT, El, ÖA, AA; Final approval and accountability: YK, PT, EI, ÖA, SÇ.

\section{Conflict of Interest}

Authors declared no conflict of interest.
Financial Disclosure

This study has been supported by Artvin Çoruh University Scientific Research Projects Coordination Department (Project No: 2017.M84.02.02).

\section{Acknowledgement}

We would like to thank Artvin Çoruh University Coordinatorship of Scientific Research Projects for their support in the realization of this study. We would like to thank Recep Tayyip Erdoğan University Rectorate, Bingöl University Rectorate, Kafkas University Rectorate, Maltepe University Rectorate for allowing the data collection stage of the study to be carried out at their institutions. We would also like to thank Assoc. Prof. Dr. Özlem Karabulutlu, Assist. Prof. Dr. Özlem Saral, Assist. Prof. Dr. Şenay Öztürk, Nurse Lecturer Melike Kanbay for their intensive support and efforts in the data collection stage.

\section{References}

1. Donelan K, DesRoches CM, Dittus RS, Buerhaus P. Perspectives of physicians and nurse practitioners on primary care practice. N Engl J Med. 2013;368(20):1898-906.

2. Cafiero M. Nurse practitioners' knowledge, experience, and intention to use health literacy strategies in clinical practice. J Health Commun. 2013;18(sup1):70-81.

3. Jefferies $H$, Chan KK. Multidisciplinary team working: is it both holistic and effective? Int J Gynecol Cancer. 2004;14(2).

4. Rajeswaran L. Clinical experiences of nursing students at a selected institute of health sciences in Botswana. Heal Sci J. 2016;10(6):1.

5. Gemuhay HM, Kalolo A, Mirisho R, Chipwaza B, Nyangena E. Factors affecting performance in clinical practice among preservice diploma nursing students in Northern Tanzania. Nurs Res Pract. 2019;2019.

6. Ümran D, Kutlutürkan $S$, Vural G. Hemşirelik dördüncü sınıf öğrencilerinin ve hemşirelerin intörnlük uygulamasına ilişkin görüşleri. Hacettepe Üniversitesi Hemşirelik Fakültesi Derg. 2008;15(2):16-25.

7. Bayar K, Çadır G, Bayar B. Hemşirelik Öğrencilerinin Klinik Uygulamaya Yönelik Düşünce ve Kaygı Düzeylerinin Belirlenmesi. TAF Prev Med Bull. 2009;8(1).

8. Dutile C, Wright N, Beauchesne M. Virtual clinical education: Going the full distance in nursing education. Newborn Infant Nurs Rev. 2011;11(1):43-8.

9. Tosun N, Oflaz F, Akyüz A, Kaya T, Yava A, Yıldız D, et al. Hemşirelik Yüksek Okulu öğrencilerinin intörn eğitim programından beklentileri ile program sonunda kazanım ve önerilerinin değerlendirilmesi. Gülhane Tıp Derg. 2008;50(3):164-71.

10. Koushali AN, Hajiamini Z, Ebadi A. Comparison of nursing students' and clinical nurses' attitude toward the nursing profession. Iran J Nurs Midwifery Res. 2012;17(5):375.

11. Aragaw Y, Sinishaw W, Daba W, Mekie M. Attitude of Nursing and Midwifery students towards clinical practice and its associated factors in Northwest Ethiopia: a cross-sectional study. BMC Res Notes. 2019;12(1):205.

12. Organization WH. Global strategic directions for strengthening nursing and midwifery 2016-2020. 2016;

13. Tagney J, Haines C. Using evidence-based practice to address gaps in nursing knowledge. Br J Nurs. 2009;18(8):484-9 
14. Haugan G, Sørensen A-H, Hanssen I. The importance of dialogue in student nurses' clinical education. Nurse Educ Today. 2012;32(4):438-42.

15. Jonsén E, Melender H-L, Hilli Y. Finnish and Swedish nursing students' experiences of their first clinical practice placement-A qualitative study. Nurse Educ Today. 2013;33(3):297-302.

16. Bisholt B, Ohlsson U, Engström AK, Johansson AS, Gustafsson $M$. Nursing students' assessment of the learning environment in different clinical settings. Nurse Educ Pract. 2014;14(3):304-10.

17. McKenna L, Gilmour C, Biro MA, McIntyre M, Bailey C, Jones J, et al. Undergraduate midwifery students' sense of belongingness in clinical practice. Nurse Educ Today. 2013;33(8):880-3.

18. Sharif $F$, Masoumi $S$. A qualitative study of nursing student experiences of clinical practice. BMC Nurs. 2005;4(1):1-7.

19. Ha E-H. Attitudes toward clinical practice in undergraduate nursing students: AQ methodology study. Nurse Educ Today. 2015;35(6):733-9.

20. Lim JY, Kim MA, Kim SY, Kim EJ, Lee JE, Ko YK. The effects of a cognitive-behavioral therapy on career attitude maturity, decision making style, and self-esteem of nursing students in Korea. Nurse Educ Today. 2010;30(8):731-6.

21. Yıldırım A, Şimşek $H$. Sosyal bilimlerde nitel araştırma yöntemleri. Ankara: Seçkin Yayınları. Introd Sect master theses Total 189 citations, Introd Sect. 2011;

22. Turan İ, Şimşek Ü, Aslan H. Eğitim araştırmalarında likert ölçeği ve likert-tipi soruların kullanımı ve analizi. Sak Üniversitesi Eğitim Fakültesi Derg. 2015;30(1):186-203.

23. DeVellis RF. Ölçek geliştirme. Kuram ve Uygulamalar (Çev Ed T Totan) Ankara Nobel Akad Yayıncilık. 2014;

24. Erkuş A. Psikolojide ölçme ve ölçek geliştirme-l: Temel kavramlar ve işlemler (2. Baskı). Ankara Pegem Akad. 2014;

25. Şeker H, Gençdoğan B. Psikolojide ve eğitimde ölçme aracı geliştirme [Development of measurement tool in psychology and education]. Ankara, Turkey: Nobel Yayın Dağıtım. 2006;

26. Şencan H. Sosyal ve davranışsal bilimlerde bilimsel araştırma. Ankara: Seçkin Yayıncılık. 2007;

27. Pallant J. SPSS Kullanma Kılavuzu, Çev: Sibel Balcı ve Berat Ahi, 2. Baskı, Anı Yayıncılık, Ankara. 2017;

28. Ho R. Handbook of univariate and multivariate data analysis and interpretation with SPSS. CRC press; 2006.

29. Tavsancıl E. Tutumlarin olcülmesi ve SPSS ile veri analizi [Measuring attitudes and data analysis with SPSS]. Ankara, Turkey: Nobel Yayin Dagitim. 2002;

30. Sönmez V, Alacapınar G. Sosyal bilimlerde ölçme aracı hazırlama. Anı Yayıncılık; 2016.

31. Can A. Quantitative data analysis with SPSS. Ankara Pegem Akad. 2017;

32. Buyukozturk S. Sosyal bilimler icin veri analizi el kitabi [Data analysis handbook for social sciences]. Ankara Pegem Akad. 2010;

33. Kline RB. Principles and practice of structural equation modeling. Guilford publications; 2015.

34. Marsh HW, Hau K-T, Artelt C, Baumert J, Peschar JL. OECD's brief selfreport measure of educational psychology's most useful affective constructs: Cross-cultural, psychometric comparisons across 25 countries. Int J Test. 2006;6(4):311-60.

35. Tezbaşaran AA. Likert tipi ölçek hazırlama kılavuzu (3. Sürüm). Mersin: e-kitap. 2008; 